\title{
Assessing climate change vulnerability for the Iberian vi- per Vipera seoanei
}

\author{
Fernando Martínez-Freiría *
}

\begin{abstract}
CIBIO/InBIO, Centro de Investigação em Biodiversidade e Recursos Genéticos da Universidade do Porto. Instituto de Ciências Agrárias de Vairão, R. Padre Armando Quintas, 4485-661 Vairão, Portugal .

*Correspondence: Phone: +351 252660400, Fax: +351 252661780, E-mail: fmartinez-freiria@cibio.up.pt
\end{abstract}

Received: 24 December 2014; returned for review: 21 September 2015; accepted 9 October 2015.

Anthropogenic climate change has the potential to completely modify patterns of biodiversity worldwide. In the Iberian Peninsula, Euro-Siberian reptiles are suggested as the most vulnerable to the effects of climate change. One of most threatened species is Vipera seoanei, for which it was forecasted a complete loss of suitable habitats already in 2020. In this work, 355 distributional records (at $1 \times 1 \mathrm{~km}$ scale) and eight climatic variables for current and future conditions (three storylines; 2050 and 2080 periods) are analysed by combining four ecological niche-based model algorithms (ANN, GAM, GLM and MAXENT) to assess $V$. seoanei vulnerability to forecasted scenarios of climatic change, and to infer potential impacts in its genetic diversity. Consensus models for current conditions fit species observational data and identify two temperature and two precipitation variables as the most related to the species distribution. Prognostics for the future predict $V$. seoanei persistence in the Iberian Peninsula for the next future, but with dramatic reductions in suitable climatic areas by 2050 and especially by 2080. Reductions might be particularly accused along the species range margins, and thus currently isolated populations at its south-western range would be highly vulnerable to extinction. Furthermore, important losses of genetic diversity and population isolation might be favoured in the future, suggesting a high vulnerability of the species to climate change, and thus the necessity of developing further studies and monitoring programs. Other species with Euro-Siberian affinity are likely to experience similar responses and would show similar vulnerability to climate change.

Key words: Biomod; Euro-Siberian affinity; genetic diversity; range contractions; reptile; Viperidae.

Evaluación de la vulnerabilidad al cambio climático en la víbora ibérica Vipera seoanei. El cambio climático antropogénico tiene el potencial de modificar completamente los patrones de biodiversidad en todo el mundo. En la Península Ibérica, se ha sugerido que los reptiles eurosiberianos son los más vulnerables a los efectos del cambio climático. Uno de los más amenazados es Vipera seoanei, para la que se prevé una pérdida completa de hábitats adecuados en 2020. En este trabajo se analizan 355 observaciones (a escala 1 x $1 \mathrm{~km}$ ) y ocho variables climáticas para las condiciones actuales y futuras (tres líneas de historia; años 2050 y 2080) mediante la combinación de cuatro algoritmos de modelado de nicho ecológico (ANN, GAM, GLM y MAXENT) para evaluar la vulnerabilidad de $V$. seoanei a los escenarios pronosticados de cambio climático y estimar potenciales pérdidas en su diversidad genética. Los modelos de consenso para las condiciones actuales se ajustan a la distribución de las observaciones de la especie e identifican dos variables de temperatura y dos de precipitación como las más relacionadas con la distribución de la especie. Los pronósticos para el futuro predicen la 
persistencia de $V$. seoanei en la Península Ibérica, aunque con dramáticas reducciones de las zonas climáticas adecuadas para el 2050 y especialmente para 2080. Las reducciones podrían ser particularmente acusadas en los márgenes de su distribución y por lo tanto las poblaciones, actualmente aisladas, del suroeste de su distribución podrían ser muy vulnerables a la extinción. Además, en el futuro se podrían favorecer importantes pérdidas de la diversidad genética y aislamientos poblacionales, lo que sugiere una alta vulnerabilidad de la especie al cambio climático y por lo tanto una gran necesidad de desarrollar más estudios y programas de monitorización. Otras especies con afinidad eurosiberiana son potencialmente propensas a experimentar respuestas similares y mostrarían un grado similar de vulnerabilidad al cambio climático.

Key words: afinidad eurosiberiana; Biomod; contracciones del rango de distribución; diversidad genética; reptil; Viperidae.

Anthropogenic climate change is a major threat to global biodiversity (Рімм, 2008; Butchart et al., 2010). Empirical evidences inform that environmental changes are currently affecting all the levels of terrestrial ecosystems (PARMESAN, 2006; MACLEAN \& Wilson, 2011). Prognostics for the near future warn of dramatic alterations in the distribution of natural habitats, which would ultimately modify biodiversity patterns (e.g. Thomas et al., 2004; Malcolm et al., 2006). For some species, evolutionary and / or ecological adaptations would allow in situ prevalence but many others will probably face local extinctions (Hoffmann \& Sgrò, 2011). Dispersal capabilities could allow species to move together with their environments; however, for species with limited capacities of dispersion, tracking of environmental shifts is unlikely, and they should be more vulnerable to extinction processes (PARMESAN, 2006; HofFMANN \& SGRò, 2011). Integrating different factors related to species responses to climate change is key for assessing species vulnerabilities and applying coherent conservation strategies.

Reptiles are particularly vulnerable to climate change, as they usually present high environmental specificity (ectothermic physiology) and frequently present reduced dispersal abilities (Pough, 1980; Sinervo et al., 2010). Climate change has been predicted to exert negative impacts over reptiles worldwide, including shifts in abundance and activity patterns, range fragmentation, and elimination of suitable habitats (GibBons et al., 2000; SINERvo et al., 2010). Yet, these effects would vary geographically (e.g. in latitude and altitude) and also due to the ecological requirements of species (e.g. SInERvo et al., 2010; Martínez-Freiría et al., 2013). For Southern Europe, climate change is predicted to be severe, with increases of temperature ranging from 1 to $10^{\circ} \mathrm{C}$ until the end of this century, which would favour the expansion of arid environments (IPCC, 2013). Accordingly, climate change assessments performed at continental and regional level predicted dramatic shifts in distributional ranges of reptiles; particularly, Euro-Siberian species inhabiting the Iberian Peninsula were identified as the most vulnerable to extinction (Araújo et al., 2006; CARvalHo et al., 2010). One of most threatened species is Vipera seoanei, for which it was forecasted a complete loss of 
suitable habitats already in 2020 (CARvalho et al., 2010). However, the coarse resolution used in these studies (e.g. $10 \mathrm{x}$ $10 \mathrm{~km}$ of pixel size; Carvalho et al. 2010) could have prevented the identification of potential micro-climates likely acting as refugia under climate change scenarios, and thus fine-scale approaches are needed.

Vipera seoanei is a nearly-Iberian endemic species restricted to northern Portugal and Spain, and entering a few kilometres in south-western France (MartínezFreiría \& Brito, 2014). It inhabits sparse forests, scrublands and meadows with Atlantic climate, with populations ranging from the sea level to $1900 \mathrm{~m}$ in the Cantabrian Mountains (MARTínez-Freiría \& BRITO, 2014). The species is included in the Pelias clade, being closely related to $V$. berus, from which it probably diverged in the Pliocene (GARrigues et al., 2005; UrseNBACHER et al., 2006; MARTínez-Freiría et al., 2015). Vipera seoanei presents shallow phylogeographic structure and low haplotype diversity (Figs. 1a,b), likely as consequence of the warming periods of the late Pleistocene that confined populations to northwestern Iberia (MARTínez-Freiría et al., 2015). Conversely, it exhibits high morphological variability, which seems related to the occurrence of environmental gradients, thus suggesting an important role of local adaptation in the species (MARTínezFreiría \& Brito, 2013; MARtínez-Freiría et al., 2015). Regarding conservation status, $V$. seoanei is considered as of Least Concern (LC) because is presumed to be frequent along its range and presents high effective population densities (Pleguezuelos et al., 2009). However, Portuguese populations are considered as Endangered (EN) because they are isolated and vulnerable to habitat loss (BRITO, 2008), a threat that also affects some southern populations in Spain (BRAÑA, 2002) and north-eastern populations in France (UICN FrANCE et al., 2009).

In this work, fine-scale ecological nichebased models (at $1 \times 1 \mathrm{~km}$ of pixel size), incorporating four algorithms, are performed to assess $V$. seoanei vulnerability to forecasted scenarios of climatic change, and to infer potential impacts in the genetic diversity of the species. The study is aimed to answer the following questions: (1) Which are the environmental factors related to $V$. seoanei distribution? (2) Where are the potential areas for its current occurrence located? (3) Where will the potential areas for its future occurrence located? (4) Which are the most vulnerable populations to climate change? (5) How will potential future reductions in suitable areas for the species affect to its genetic diversity? The present work is expected to provide insights on the vulnerability to climate change of $V$. seoanei and to contribute to local-scale conservation of populations.

\section{Materials and Methods}

\section{Data}

A total of 355 distributional records at 1 x 1 km (WGS 1980 datum) were gathered from field-work carried out from 1999 to 2013 ( $\mathrm{N}=104)$ and from georeferenced specimens from eight museum collections ( $\mathrm{N}=251$; see MArtínez-Freiría \& Brito, 2013). To avoid spatial bias in ecological modelling procedures (see SILlERo et al., 2010), the level of spatial clustering in species presence was decreased by a random 

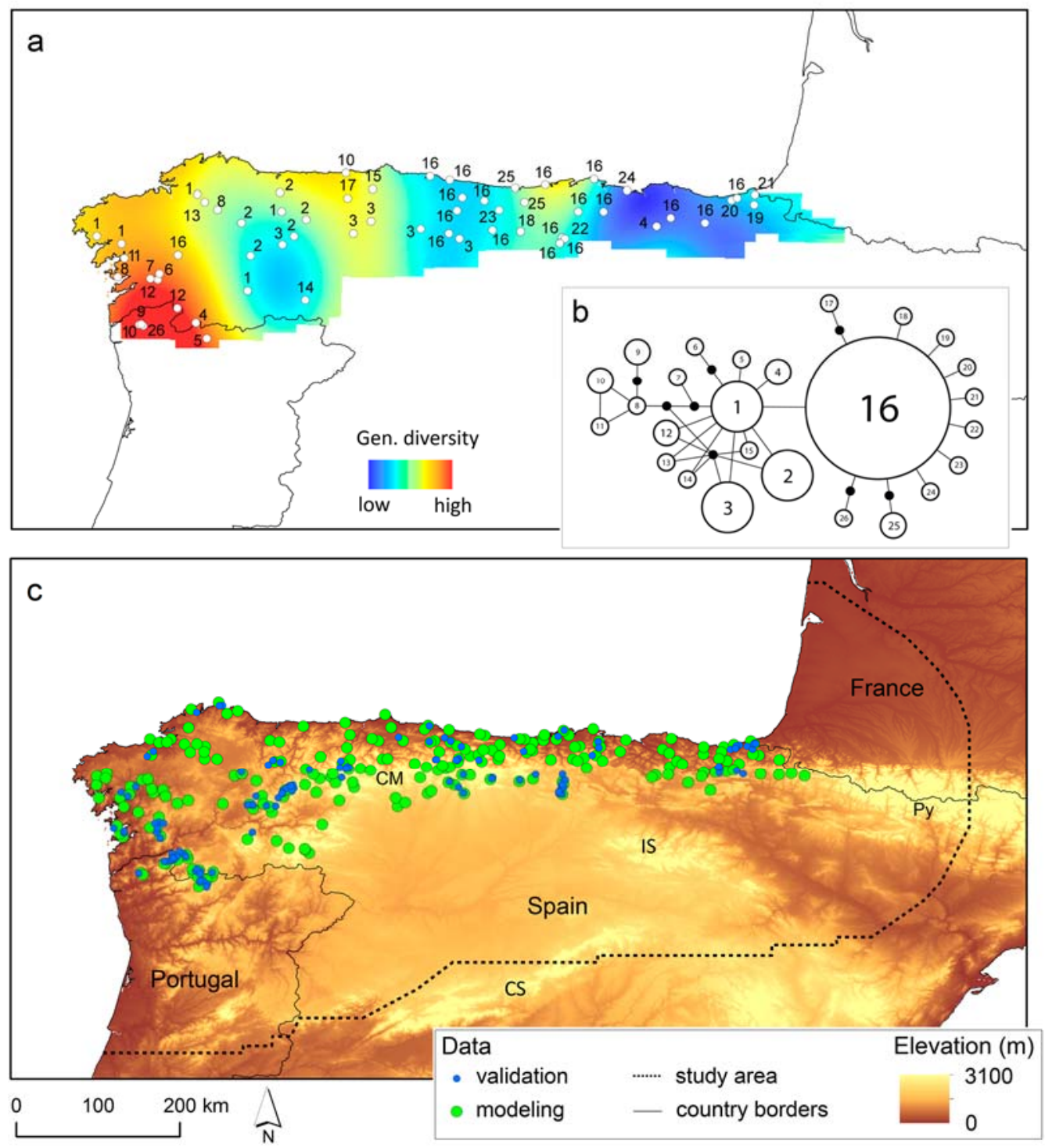

Figure 1: (a) Surface of interpolated mitochondrial haplotype diversity for Vipera seoanei, with the distribution of haplotypes (60 samples) signalled as numbers. (b) Haplotype network (ND4 and cytb) for $V$. seoanei showing the relationships between haplotypes mapped in (a). The size of the circles corresponds to the number of samples identified within each haplotype. (c) Distribution of $V$. seoanei localities used for performing (modeling) and validating (validation) ecological models in the study area. CM: Cantabrian Mountains, CS: Central System, IS: Iberian System, Py: Pyrenees. Sections (a) and (b) adapted from Martínez-Freiría et al. (2015). For an optimal visualisation, consult the online, coloured version.

process of removing localities from clusters of species occurrence (for details see
Martínez-Freiría et al., 2015). Finally, a total of 217 presences (with a minimum 
Table 1: Climatic variables used for ecological niche-based models, depicting codes, names, ranges for current conditions and units.

\begin{tabular}{llcc}
\hline Code & Name & Range & Units \\
\hline bio 3 & Isothermality (P2 / P7) $\left({ }^{*} 100\right)$ & $30-46$ & var. coef. \\
bio 6 & Min Temperature of Coldest Month & $-10.5-7.9$ & ${ }^{\circ} \mathrm{C}$ \\
bio 8 & Mean Temperature of Wettest Quarter & $-16-174$ & ${ }^{\circ} \mathrm{C}$ \\
bio 9 & Mean Temperature of Driest Quarter & $-1.5-23.6$ & ${ }^{\circ} \mathrm{C}$ \\
bio 10 & Mean Temperature of Warmest Quarter & $64-236$ & ${ }^{\circ} \mathrm{C}$ \\
bio 15 & Precipitation Seasonality & $11-58$ & var. coef. \\
bio 17 & Precipitation of Driest Quarter & $40-338$ & $\mathrm{~mm}$ \\
bio 19 & Precipitation of Coldest Quarter & $64-711$ & $\mathrm{~mm}$ \\
\hline
\end{tabular}

distance of $5 \mathrm{~km}$ in between) were used for performing ecological models (model observations; Fig. 1c), while the remaining 138 presences were used for a secondary test of ecological models (validation observations; Fig. 1c).

\section{Climatic variables}

For current conditions, 19 climatic variables at 30 arc-seconds $(\sim 1 \times 1 \mathrm{~km})$ were downloaded from WorldClim (Hujmans et al., 2005). Spatial correlation among climatic variables was tested using the 'Band Collection Statistics' tool of ARCGIS (ESRI, 2006) and only eight slightly correlated ( $R$ $<0.58)$ variables were chosen for modelling purposes (see Table 1). These climatic variables are commonly used in ecological niche-based modelling approaches used for this and another viper species (e.g. Martínez-Freiría et al., 2008, 2015; Brito et al., 2011; ScAli et al., 2011; Yousefi et al., 2015).

For future conditions, the same eight climatic variables chosen for current conditions were obtained for the $4^{\text {th }}$ International Panel for Climate Change (IPCC) from the Global Circulation Model (GCM) data portal (http://www.ccafsclimate.org/). The $4^{\text {th }}$ IPCC was used instead of the $5^{\text {th }}$ IPCC due to unavailability for ranking the regional performance of the $5^{\text {th }}$ IPCC GCMs (see below). Recent comparisons of climatic scenarios showed a remarkable equivalency between the three storylines of the $4^{\text {th }}$ IPCC and the three high emission scenarios of the $5^{\text {th }}$ IPCC (Knutti \& SedláčEK, 2013). Climatic variables for future scenarios of climate change were at 30 arc-seconds and included prognostics for two periods (decades of 2050s and 2080s), three $4^{\text {th }}$ IPCC storylines (a1b, a2 and b1) and five GCM (ECHO-G, UKHADCM3, CSIRO-30, CCSM-30 and MPIECH-5). The IPCC storylines describe the relationships between the forces driving greenhouse gas and aerosol emissions, such as demographic, social, economic, and technological and environmental developments (CARTER, 2007). The three storylines used for this study assume different population developments, energy requirements and fuel emissions (CARTER, 2007): a1b: fast population growth, maximum energy requirements and emissions balanced across fossil and non-fossil 
sources; a2: fast population growth, high energy requirements and emissions less than fossil intensive; and b1: similar population as current time, and minimum energy requirements and emissions. The five GCMs were chosen based on a rank assessment of regional performance of available GCMs using MAGICC / SCENGEN 5.3 software following the procedures described in Fordham et al. (2011). Climatic variables for the five GCMs were averaged, obtaining six ensemble GCMs, one for each storyline and period (FordHAm et al., 2011, 2012; Martínez-Freiría et al., 2013): a1b-2050, a1b-2080, a2-2050, a2-2080, b1-2050 and b1-2080.

\section{Ecological modelling procedures}

Ecological models were performed on BIOMOD 2 ver 1.0 (Thuiller et al., 2012), a multi-model platform implemented on $\mathrm{R}$ which allows using different algorithms, deriving ensemble forecast models, and project model predictions to different climatic conditions. Four different modelling algorithms, including two regressionbased (GLM, Generalised Linear Models; and GAM, Generalised Additive Models) and two machine learning-based ones (ANN, Artificial Neural Networks; and MAXENT, Maximum Entropy), were chosen in order to reduce uncertainties derived from modelling techniques (see Wiens et al., 2009) and because they were reported to have high performances and to successfully work in many ecological modelling studies (e.g. Carvalho et al., 2010; Martínez-Freiría et al., 2013, 2015). Model algorithms were set with default parameters (see Thuiller et al., 2012).

As confirmed absences are difficult to obtain, especially for secretive species such as vipers, pseudo-absences are usually derived from the study area (e.g. MARtínez-Freiría et al., 2013, 2015). Presence records were imported into BIOMOD within a study area of $200 \mathrm{~km}$ buffer around them. This area was chosen after calibration exercises with different sizes of the study area in order to avoid bias when selecting pseudo-absences and contemplate potential species dispersal in future scenarios (VanDerWal et al., 2009; ANDersON \& RAZA, 2010). In order to address potential sample bias in pseudo-absences (Elith et al., 2010), five different pseudoabsence datasets were created. Each pseudo-absence dataset accounted for 2170 pseudo-absences (10 times the number of presence data); this strategy was chosen to obtain the most accurate results reported using regression and machine-learning algorithms (see BARBEt-Massin et al., 2012). Pseudo-absences were randomly selected using the "disk function" of Biomod at $0.33^{\circ}$ of distance from presence data (see Thuiller et al., 2012). This distance guarantees that pseudo-absence data were located outside the species range, and thus pseudo-absences were really attributable to species absences. The number of pseudo-absences was chosen to have the same weight than presence data in the calibration process of the models (i.e. prevalence $=0.5$ ).

Ten model replicates were run for each of the five pseudo-absence datasets and for each of the six algorithms, totally accounting for 200 replicates. Presence data for each replicate were selected randomly by cross-validation, using $70-30 \%$ of presence data for training-testing, respectively. 
Replicates were rescaled using a binomial GLM to ensure that all of them were comparable in terms of scale (Thuiller et al., 2012). Individual model replicates performance was evaluated using the True Skill Statistic (TSS) metric, which relates the number of correct predicted presences and absences (see AlLouche et al., 2006); only replicates with TSS $>0.95$ were kept for subsequent processes. This value was chosen after visualization of model outputs and as a compromise between performance and geographic fitness to species distribution. Individual model replicates were added to generate a consensus model under current conditions (MARTínezFreiría et al., 2008, 2013, 2015; MARMion et al., 2009). Spatial agreement among replicas was considered by displaying the coefficient of variation among them (THUILLER $e t$ al., 2012). Validation samples $(\mathrm{N}=138)$ were used for a secondary test over the consensus model for current conditions.

The importance of the climatic variables to the average (by algorithm and consensus models) was evaluated by averaging the relative contribution to individual model replicates (Martínez-Freiría et al., 2013, 2015). Univariate average response curve profiles were generated for most common important variables to model algorithms.

Individual model replicates were projected to future (a1b-2050, a1b-2080, a22050, a2-2080, b1-2050 and b1-2080) climatic conditions. Projections were assessed using clamping masks, which inform of those environmental conditions for the different scenarios outside the current range of climatic conditions (Ецiтh et al., 2010). Then, individual model replicates were added to generate a consensus model of species presence under each future period (Martínez-Freiría et al., 2008, 2013; Marmion et al., 2009). Similarly to consensus model for current conditions, consensus projections were spatially assessed by displaying the coefficient of variation among replicas (Thuiller et al., 2012).

To investigate if species range was predicted to contract or expand, consensus models and projections to scenarios of climate change were converted to a binary value of predicted presence / absence using the optimized threshold from the receiver operating characteristics plot that maximizes sensitivity and specificity. This threshold, commonly used in climate change assessments (e.g. Lemes \& Loyola, 2013; Martínez-Freiría et al., 2013), delimits the area for which presences and pseudo-absences are correctly predicted, i.e., sensitivity and specificity, respectively (Liu et al., 2005). Areas of predicted presence by the consensus binary model for current conditions and projections to scenarios of climate change were compared in the ARCGIS.

\section{Inference on the genetic diversity loss of the species}

In order to infer potential loses in the genetic diversity of $V$. seoanei under scenarios of climate change, consensus binary projections to scenarios of climate change derived from ecological models were overlapped with the distribution of the $26 \mathrm{mi}-$ tochondrial haplotypes already known for the species (Fig 1a; Martínez-Freiría et al., 2015). The identification of haplotypes resulted from Bayesian inference on two mitochondrial gene regions (ND4 and Cy- 
Table 2: Average (Avg) and standard deviation (SD) TSS values, number of replicates with TSS $>0.95$, average TSS threshold value that maximise Sensitivity and Specificity, average maximum values for Sensitivity and Specificity, and percentage of correct classified validation samples (\% CC), for each model algorithm. Replicates with TSS $<0.95$ were not considered for projecting and / or ensemble forecasting.

\begin{tabular}{lcccccc}
\hline Algorithm & Avg (SD) & N replicates & Threshold & Sensitivity & Specificity & \% CC \\
\hline ANN & $0.975(0.013)$ & 45 & 0.424 & 98.496 & 98.959 & 100.0 \\
GAM & $0.999(0.004)$ & 50 & 0.495 & 100.000 & 100.000 & 100.0 \\
GLM & $0.975(0.997)$ & 38 & 0.476 & 98.786 & 88.568 & 100.0 \\
MAXENT & $0.969(0.013)$ & 33 & 0.503 & 98.695 & 98.236 & 100.0 \\
\hline
\end{tabular}

Table 3: Average (and standard deviation) contribution of variables to each model algorithm and to the consensus model. The most important variables to each average model by algorithm and to the consensus model are signalled in bold. See Table 1 for variables names.

\begin{tabular}{lcccccccc}
\hline Algorithm & bio 3 & bio 6 & bio 8 & bio 9 & bio 10 & bio 15 & bio 17 & bio 19 \\
\hline \multirow{2}{*}{ ANN } & 0.123 & $\mathbf{0 . 5 3 3}$ & 0.248 & 0.357 & $\mathbf{0 . 5 8 3}$ & $\mathbf{0 . 4 8 1}$ & $\mathbf{0 . 8 0 9}$ & $\mathbf{0 . 6 5 8}$ \\
& $(0.054)$ & $\mathbf{( 0 . 0 8 9 )}$ & $(0.114)$ & $(0.145)$ & $\mathbf{( 0 . 2 0 7 )}$ & $\mathbf{( 0 . 1 5 5 )}$ & $\mathbf{( 0 . 0 9 3 )}$ & $\mathbf{( 0 . 1 0 4 )}$ \\
GAM & 0.089 & $\mathbf{0 . 5 6 4}$ & 0.185 & 0.363 & $\mathbf{0 . 8 0 6}$ & $\mathbf{0 . 6 2 0}$ & 0.388 & 0.432 \\
& $(0.029)$ & $\mathbf{( 0 . 1 3 3 )}$ & $(0.141)$ & $(0.118)$ & $\mathbf{( 0 . 0 8 1 )}$ & $\mathbf{( 0 . 0 8 7 )}$ & $(0.183)$ & $(0.272)$ \\
\multirow{2}{*}{ GLM } & 0.069 & $\mathbf{0 . 6 6 6}$ & 0.104 & 0.262 & $\mathbf{0 . 8 2 3}$ & $\mathbf{0 . 5 3 3}$ & 0.278 & 0.206 \\
& $(0.053)$ & $\mathbf{( 0 . 0 7 9 )}$ & $(0.060)$ & $(0.145)$ & $\mathbf{( 0 . 0 7 1 )}$ & $\mathbf{( 0 . 0 9 3 )}$ & $(0.255)$ & $(0.166)$ \\
\multirow{2}{*}{ MAXENT } & 0.003 & 0.320 & 0.036 & 0.071 & $\mathbf{0 . 4 9 7}$ & $\mathbf{0 . 4 0 0}$ & $\mathbf{0 . 5 1 4}$ & 0.070 \\
& $(0.001)$ & $(0.056)$ & $(0.016)$ & $(0.038)$ & $\mathbf{( 0 . 0 6 2 )}$ & $\mathbf{( 0 . 0 7 1 )}$ & $\mathbf{( 0 . 1 2 0 )}$ & $(0.032)$ \\
\multirow{2}{*}{ Consensus } & 0.071 & $\mathbf{0 . 5 2 1}$ & 0.143 & 0.263 & $\mathbf{0 . 6 7 7}$ & $\mathbf{0 . 5 0 9}$ & $\mathbf{0 . 4 9 7}$ & 0.342 \\
& $(0.021)$ & $\mathbf{( 0 . 0 2 8 )}$ & $(0.049)$ & $(0.044)$ & $\mathbf{( 0 . 0 5 9 )}$ & $\mathbf{( 0 . 0 3 2 )}$ & $\mathbf{( 0 . 0 5 2 )}$ & $(0.088)$ \\
\hline
\end{tabular}

tochrome $b ; 1184 \mathrm{bp}$ in total) obtained for 60 samples covering the species distribution (for details see Martínez-Freiría et al., 2015). Due to the non-uniform spatial coverage in the distribution of haplotypes (see Fig. 1a), overlap estimations accounted for all haplotypes located within a maximum distance of $20 \mathrm{~km}$ from pixels with predicted presence for each scenario. This distance was arbitrarily selected in order to reflect the average distance between samples, which corresponds to $18.5 \mathrm{~km}$. Both the total number of haplotypes and the percentage of each haplotype loss were calculated. Overlap analyses were done in the ARCGIS and represented on the haplo- type network (sensu PAUls et al., 2013).

\section{RESULTS}

\section{Ecological niche-based models}

A total of 166 replicas with TSS $>0.95$ were used for deriving the consensus model, being GAM and MAXENT the algorithms which more and less contributed to it, respectively. All validation samples were correctly classified in the four average models by algorithm (Table 2).

Two temperature (Min Temperature of Coldest Month and Mean Temperature of Warmest Quarter) and two precipitation (Precipitation Seasonality and Precipita- 

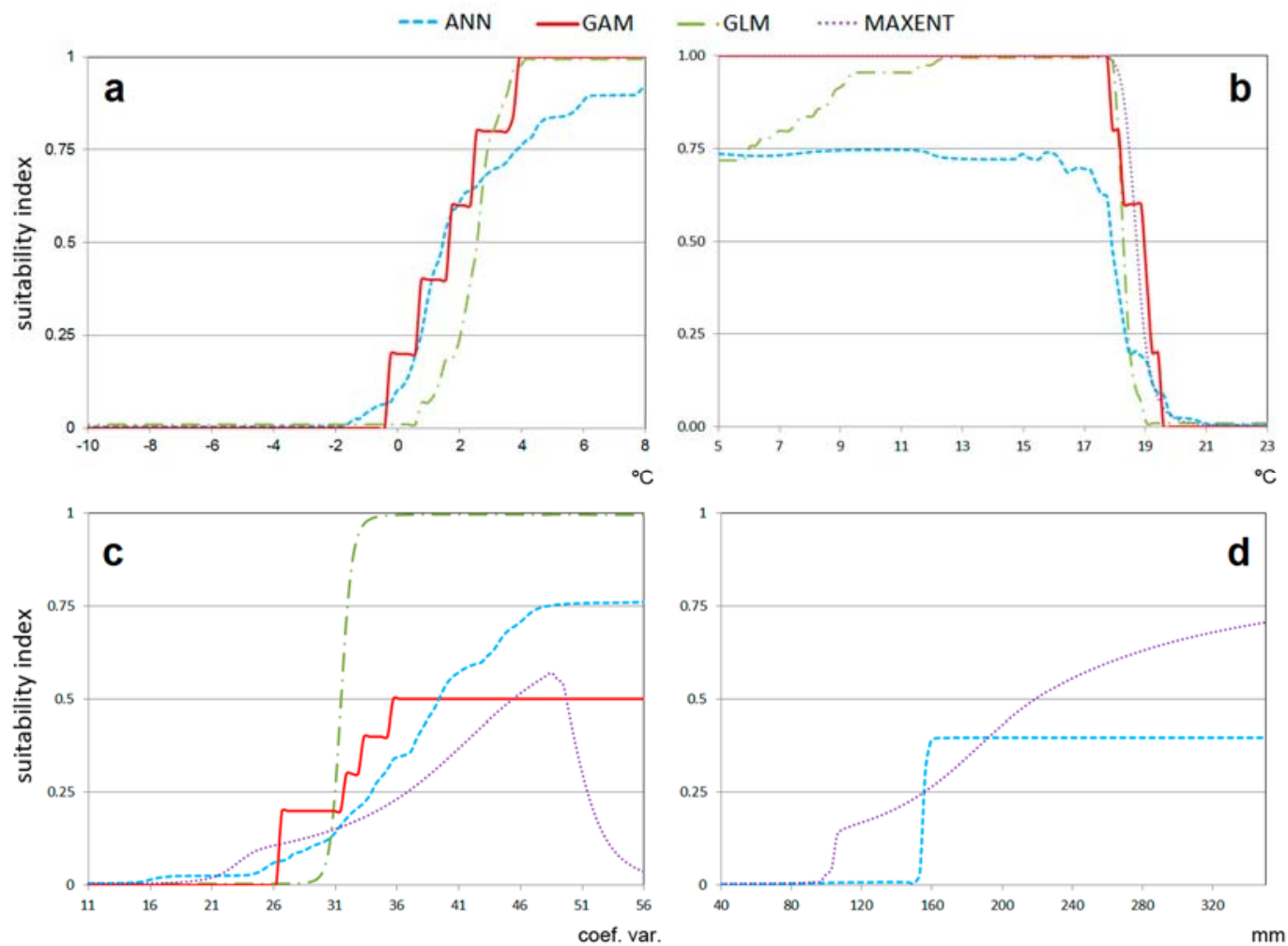

Figure 2: Average response curve profiles for the most important variables to each ecological modelling algorithm. (a) Minimum Temperature of Coldest Month. (b) Mean Temperature of Warmest Quarter. (c) Precipitation Seasonality. (d) Precipitation of Driest Quarter.

tion of Driest Quarter) variables were found as the most related to the species distribution (Table 3). Response curve profiles for these four important variables showed similar patterns for the four algorithms (Fig. 2). In general, $V$. seoanei avoids extremely cold and warm areas during the coldest and warmest periods, respectively, and areas with low precipitation seasonality and low levels of precipitation during the driest periods.

The suitability and binary consensus models for current conditions fit species observational data, with the highest values of coefficient of variation between replicas located at the species range margins (Fig. 3). The binary consensus model for current conditions predicted an area of $70967 \mathrm{~km}^{2}$ as suitable for the species, which corresponds to $38.48 \%$ of the study area.

\section{Projection to future conditions}

Consensus projections derived for future conditions were very similar regarding the three different storylines but showed dissimilarities when years were compared (Figs. 4, S1).

Consensus binary projections for 2050 mostly showed north-western and northcentral regions and some patches in the 
east and south-west of the study area as suitable for the species (Figs. 4, S1). These projections represent on average a $24.67 \%$ of the suitable area when compared to consensus model for current conditions (Table 4).

Consensus binary projections for 2080 mainly identified high-elevation mountains in north-western and north-central regions as suitable for the species (Figs. 4, $\mathrm{S1}$ ). These projections represent on average a $6.58 \%$ of the suitable area when compared to consensus model for current conditions (Table 4).
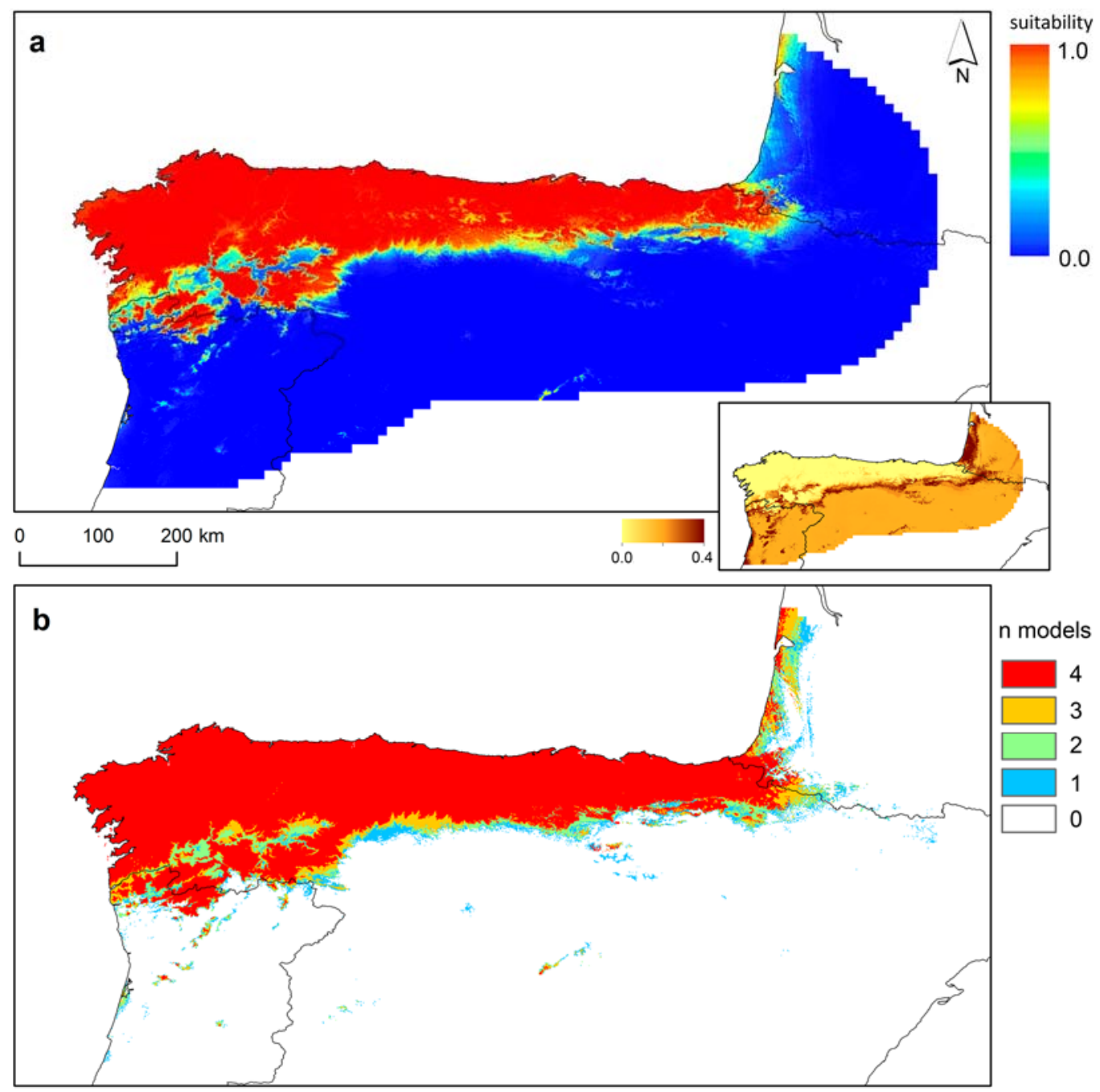

Figure 3: Consensus model for current climatic conditions retrieved from the best performing replicas ( $\mathrm{N}=166$; TSS > 0.95), displayed by (a) suitability, coefficient of variation (small inset), and (b) by sum of average binary models per algorithm. For an optimal visualisation, consult the online, coloured version. 

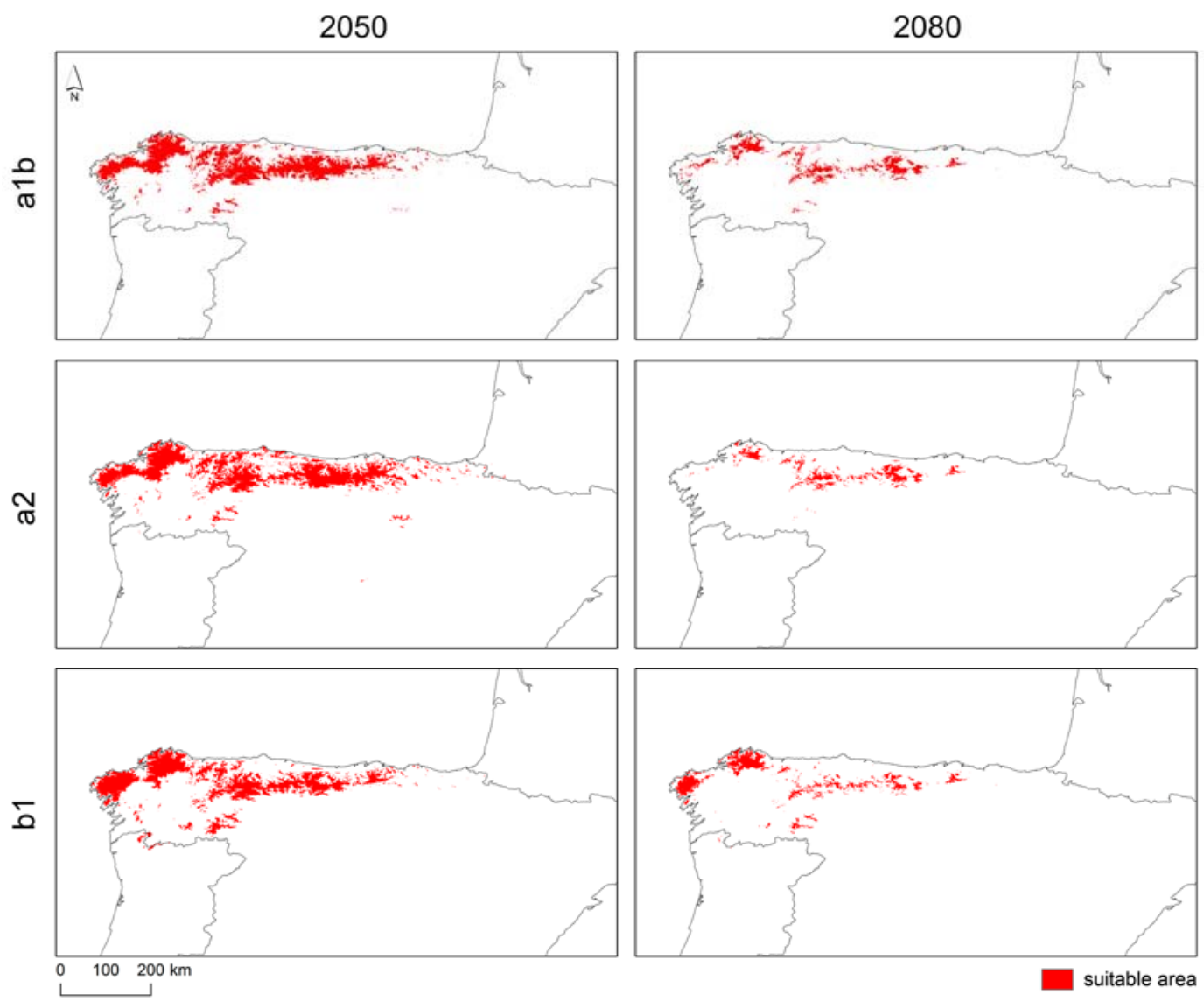

Figure 4: Binary projections of ecological models developed for Vipera seoanei into future climatic conditions, including average conditions from five global circulation models for three $4^{\text {th }}$ IPCC storylines (a1b, a2 and b1) and two periods (2050s and 2080s).

Table 4: Suitable area (in $\mathrm{km}^{2}$ ) and \% of suitable area in relation to current scenario predicted for Vipera seoanei from consensus binary models (current) and projections to scenarios of climate change (combinations of three storylines -a1b, a2 and b1- and two time periods -2050 and 2080-), and estimates for the number of haplotypes and \% of total haplotypes reported for the species in current times resulted from the overlap analyses with suitable areas for each scenario of climate change.

\begin{tabular}{lcccc}
\hline Scenario & Area & \% current & N haplotypes & \% haplotypes \\
\hline current & 70967 & 100.00 & 26 & 100.00 \\
a1b 2050 & 17565 & 24.75 & 20 & 76.92 \\
a2 2050 & 18800 & 26.49 & 21 & 80.77 \\
b1 2050 & 16155 & 22.76 & 20 & 76.92 \\
a1b 2080 & 5016 & 7.07 & 12 & 46.15 \\
a2 2080 & 3358 & 4.73 & 9 & 34.62 \\
b1 2080 & 5639 & 7.95 & 12 & 46.15 \\
\hline
\end{tabular}



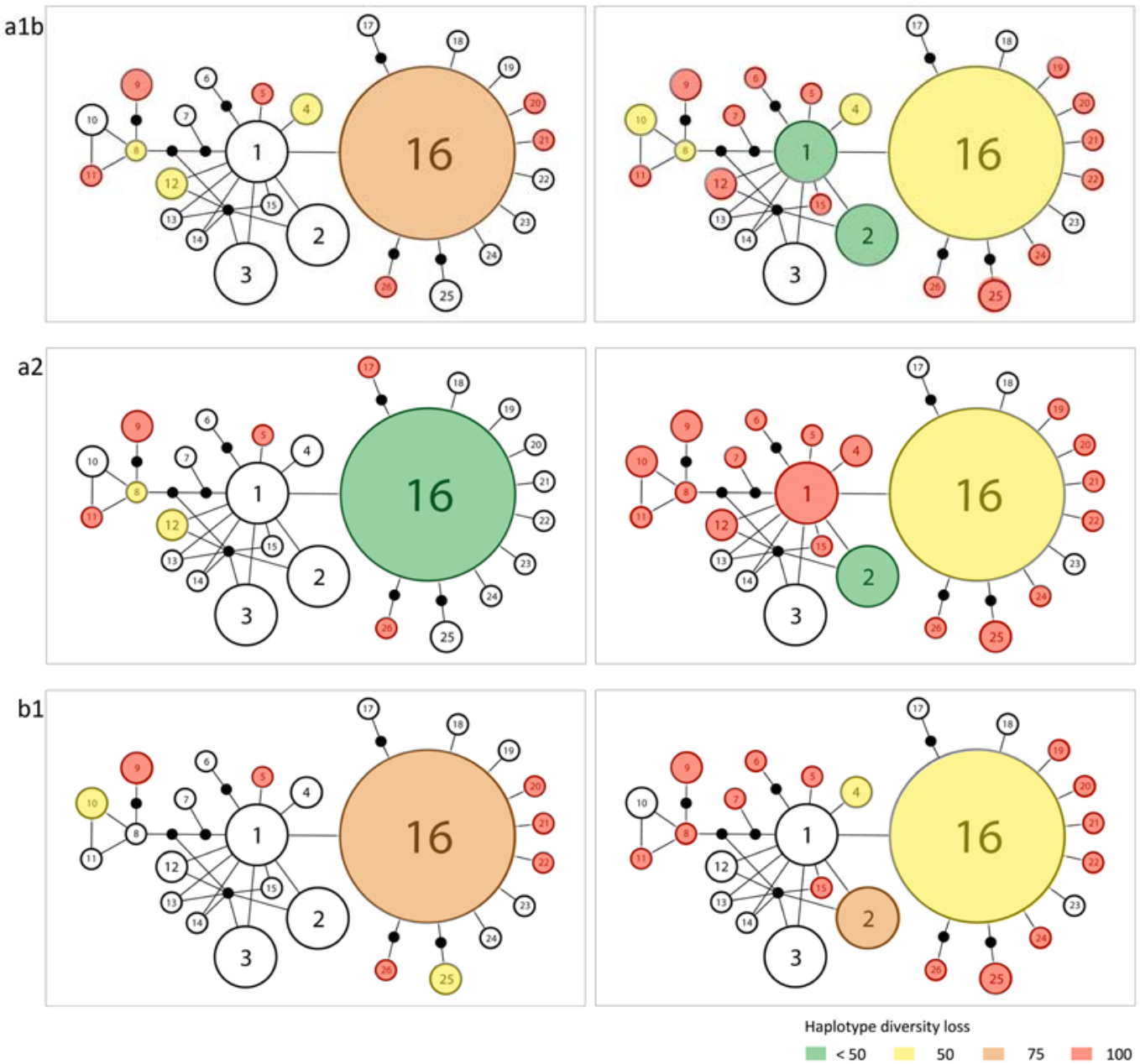

Figure 5: Estimates of haplotype diversity loss in Vipera seoanei, inferred from overlap analyses between the distribution of haplotypes and binary projections of ecological models into future climatic conditions (including average conditions from five global circulation models for three $4^{\text {th }}$ IPCC storylines -a1b, a2 and b1-, and two periods -2050s and 2080s-). The size of the circles corresponds to the number of samples identified within each haplotype, while colours represent categories for the percentage of each haplotype loss in relation to current haplotype diversity. Haplotype network adapted from Martínez-Freiría et al. (2015). For an optimal visualisation, consult the online, coloured version.

\section{Inference on the genetic diversity loss}

The overlap analyses between the distribution of haplotypes and the consensus projections for future conditions showed distinct impacts on the genetic diversity of $V$. seoanei (Table 4, Fig. 5).

In 2050, suitable areas for the species included on average 20 haplotypes $(78.2 \%$ of the total diversity; Table 4), with the 
worst scenario occurring for the a1b storyline in which reductions in suitable areas for the species affected 11 of the 26 haplotypes (Fig. 5).

In 2080, suitable areas for the species included on average 11 haplotypes (42.3\% of the total diversity; Table 4). In this period, the worst scenario occurred for the a2 storyline, with reductions affecting to 20 of the 26 haplotypes described for the species (Fig. 5)

\section{Discussion}

\section{Uncertainties in predictions}

Ecological niche-based models are source of uncertainties and limitations, and thus there is much criticism about the reliability of their predictions and their application to conservation (see Wiens et al., 2009; Dawson et al., 2011). Recently, a new era of spatially calibrated approaches aimed at incorporating important factors constraining species response to climate change at the population level is emerging (e.g. Kissling et al., 2012; Fordham et al., 2013). Such approaches require important knowledge on species biology (e.g. ecophysiological traits, adaptive capacities, dispersal rates, biotic interactions), which in many cases is inexistent and its obtainment is a time consuming process. Although static, ecological models still remain as important tools for inferring the degree of exposure of species to environmental changes (i.e. the extent of climate change likely to be experienced by a species), which is one of the three factors related to species vulnerability (see Dawson et al., 2011). Therefore, when knowledge on species biology is lacking, a reasonable strategy to infer species vulnerability to climate change is minimizing uncertainties and also referring potential caveats of the approach (e.g. Martínez-Freiría et al., 2013).

This work controlled for the impact of methodological sources of uncertainties that usually characterize climate change assessments (see WiEns et al., 2009). Other uncertainties, such as those related to the lack of incorporation of real dispersal abilities (see Araújo et al., 2006; Carvalho et al., 2010; Martínez-Freiría et al., 2013), were overlooked in this study due to unavailability of this information for the species and to resulted reductions in suitable areas for future conditions (Figs. 4, S1). Dispersal in vipers (genus Vipera) occurs in the period before sexual maturation; only a single study has reported these distances for few specimens in a limited period of time (e.g. $75-280 \mathrm{~m}$ in $V$. aspis newborns before first hibernation; SAINTGirons, 1981). Estimates of dispersal are usually derived from distances roamed by adults during the annual cycle (e.g. ca. 1 $\mathrm{km} /$ year in adult males of the other Iberian vipers; Martínez-Freiría et al., 2010) but such distances reflect how species use their home ranges. Regarding the second reason, only two regions located outside the current species range (i.e. mountains of northern Iberian and Central Systems, located at more than $80 \mathrm{~km}$ from the closest populations) were predicted as suitable in $\mathrm{a} 1 \mathrm{~b}$ and $\mathrm{a} 2$ scenarios of climate change for 2050 (see Fig. 4). It is unlikely that the species is able to naturally reach these regions in the next 40 years, even considering the distances roamed by adults from other Iberian vipers. This study takes into ac- 
count the variability of climate only, but other factors such as habitat loss are likely to interact with climate change effects, hampering or limiting species dispersal and also increasing populations' vulnerability (Brook et al., 2008; MANTYKA-PRINGLE et al., 2012).

\section{Vulnerability to climate change}

The temperate character of $V$. seoanei is totally reflected in the environmental correlates of the species identified in this study. Although it is an ectothermic species, it selects areas with moderate levels of temperature but certain degree of humidity given by high precipitation levels (Fig. 2). Similar results were obtained in other studies using ecological modelling techniques developed for this species either in contact zones with the other two Iberian vipers (BRITO \& CRESPO, 2002; MARtínez-Freiría et al., 2008; TARroso et al., 2014) or for its whole Iberian distributional range (Martínez-Freiría et al., 2015). Given the narrow geographical extension of these climatic conditions in the Iberian Peninsula and the prognosticated increases of temperature for southern Europe in future scenarios of climate change (IPCC, 2013), a significant impact of climate change in the climatic areas occupied by $V$. seoanei is therefore plausible.

Vipera seoanei was predicted to loss all suitable climatic areas in 2020 (CARvalho et al., 2010), but coarse grid cells (10 x $10 \mathrm{~km})$ used in this study could have underestimated the availability of suitable areas for the species persistence within Iberia. Prognostics of this study were developed at a much finer scale $(1 \times 1 \mathrm{~km})$ and predict $V$. seoanei persistence in the Iberian Peninsula in the immediate future, but with dramatic reductions in suitable climatic areas for 2050 and especially for 2080 (Fig. 4). These reductions largely follow south to north and east to west directions with potential persistence at high altitudes (Fig. 4). Consequently, results from this work inform that southern (south of Galicia, north of Portugal) and eastern populations (Basque Country, Navarre and south-western France), as well as most populations surrounding the Cantabrian region (northern Asturias and Cantabria, and low altitude areas from northern Castile and Leon), have a high degree of vulnerability to climate change because they are expected to progressively loss all suitable climatic areas as predictions advance in time (from present to 2080). Still, these populations could persist in situ through evolutionary and / or ecological adaptations (HoffmanN \& SGRò, 2011), and thus further studies addressing the adaptation capacity of the species are required (e.g. BuCKLEY et al., 2015).

Populations from northern Portugal and from the south-western part of the range in Spain are currently isolated and threatened by habitat loss (BRAÑA, 2002; BRITO, 2008); thus, their vulnerability is increased by the combination of both climate change and habitat loss. The progressive reduction of suitable climatic areas for the species to high altitudes would favour isolation of populations, which would hamper their interconnectivity and gene flow. Therefore, climate change would also accentuate the vulnerability of populations to demographic stochastic or inbreeding depression processes (e.g. MADSEN et al., 1996). 


\section{Relationships with genetic diversity}

The last interglacial period of the Pleistocene (LIG), characterized by a rapid increase of temperature, was suggested as forcing $V$. seoanei to contract its distributional range to north-western Iberia, being consequently related to the depletion of its genetic diversity (Martínez-Freiría et al., 2015). Results from the current study identified suitable climatic areas for the species in 2050 that are very similar in geographic extension and configuration to suitable climatic areas obtained for the LIG (see Martínez-Freiría et al., 2015), suggesting that moderate levels of current genetic diversity would still persist in 2050. In fact, the overlap analyses between the distribution of mitochondrial haplotypes and suitable areas for 2050 recovered $78 \%$ of haplotypes inside them. Conversely, predictions for 2080 indicate important losses of genetic diversity due to a general and extensive reduction of suitable areas and the specific disappearance of high genetic diversity suitable areas such as northern Portugal or the Atlantic coast (see Fig. 1a). Accordingly, only $42.3 \%$ of the genetic diversity found in $V$. seoanei was recovered in the overlap analyses for the 2080 period. Although these calculations are based on a limited sampling of two mitochondrial markers only and do not consider possible gene flow processes with adjacent populations favoured by dispersal, they provide a reasonable estimation of the potential genetic diversity loss that can face $V$. seoane $i$ in the future (e.g. Pauls et al., 2013). Further studies with a more extensive sampling, using other molecular markers (e.g. fast evolving nuclear markers), and testing gene flow between popu- lations should be developed to better address these issues (e.g. Velo-Antón et al., 2013).

\section{Conclusion}

Vipera seoanei is predicted to lose a dramatic proportion of its current suitable climatic range under future scenarios of climate change. This would increase the vulnerability of many populations, particularly along the margins of the species distribution range, and favour an important loss of genetic diversity. Notwithstanding the static nature of the used correlative approach and the necessity of developing further studies including additional factors constraining populations responses to climate change, it is recommendable to advance in monitoring programs of populations in order to effectively measure population trends, in order to anticipate any type of conservation management that could be needed in the future.

Results from this work inform about the fragility to climate change of northern Iberian temperate areas and suggest that similar responses to climate change might occur in species sharing ecological requirements with $V$. seoanei. Approximately 18 species of reptiles with Euro-Siberian affinity occur in northern Iberia, constituting more than $35 \%$ of the reptiles of the Iberian Peninsula (Sillero et al., 2009, 2014). Particularly, some species have restricted ranges (e.g. Iberolacerta sp.; Sillero et al., 2014) and / or are harbouring much of their genetic diversity in southern ranges (e.g. Lacerta schreiberi; Paulo et al., 2001), which, in accordance to this study, might increase vulnerability to climate change. 
Therefore, climate change assessments at fine scale, preferentially including factors constraining populations' response to climate change, should be developed for these species as a way to estimate their vulnerabilities and accordingly develop conservation programs.

\section{Acknowledgement}

My acknowledgements to all persons who helped in fieldwork campaigns and / or provided distributional records: A. Pérez, A. Lamosa, I. Santidrián, G. VeloAntón, X. Pardavila, F. Álvares, M. Cabana, L. García-Cardenete, P. Sierra and J. C. Brito; to persons from museum collections who facilitated the accession to specimens, $X$. Guerra from Museo Luis Iglesias-USC (Santiago de Compostela, Spain), P. Galán from Univ. da Coruña (A Coruña, Spain), F. Braña from Univ. Oviedo (Oviedo, Spain), A. Gosá and I. Garin from Soc. Ciencias Aranzadi (Donostia, Spain), J. E. González from MNCN (Madrid, Spain), M. P. da Sousa from Paisagem Protegida Corno do Bico (Paredes de Coura, Portugal), M ${ }^{\mathrm{a}}$ V. Martínez and J. Cabot from EBD-CSIC (Seville, Spain), and M. Lizana from Univ. Salamanca (Salamanca, Spain); and to N. Sillero, M. A. L. Zuffi, G. F. Ficetola and one anonymous reviewer for revisions and comments on the early version of this manuscript. I am supported by Fundação para a Ciência e Tecnologia from Portugal (SFRH/BPD/69857/2010). This work was supported by a Systematics Research Fund project in 2012.

\section{REFERENCES}

Allouche, O.; Tsoar, A. \& Kadmon, R. (2006). Assessing the accuracy of species distribu- tion models: prevalence, kappa and the true skill statistic (TSS). Journal of Applied Ecology 43: 1223-1232.

Anderson, R.P. \& RAZA, A. (2010). The effect of the extent of the study region on GIS models of species geographic distributions and estimates of niche evolution: preliminary tests with montane rodents (genus Nephelomys) in Venezuela. Journal of Biogeography 37: 1378-1393.

Araújo, M.B.; Thuiller, W. \& Pearson, R.G. (2006). Climate warming and the decline of amphibians and reptiles in Europe. Journal of Biogeography 33: 1712-1728.

Barbet-Massin, M.; Jiguet, F.; Albert, C.H. \& Thuiller, W. (2012). Selecting pseudoabsences for species distribution models: how, where and how many? Methods in Ecology and Evolution 3: 327-338.

Braña, F. (2002). Vipera seoanei Lataste, 1879. Víbora de Seoane, In J.M. Pleguezuelos, R. Márquez \& M. Lizana (eds.) Atlas y Libro Rojo de los Anfibios y Reptiles de España. Dirección General de Conservación de la Naturaleza, Asociación Herpetológica Española, Madrid, Spain, pp. 302-303.

BRito, J.C. (2008). Vipera seoanei Lataste, 1879, In A. Loureiro, N. Ferrand De Almeida, M.A. Carretero \& O.S. Paulo (eds.) Atlas dos Anfibios e Répteis de Portugal, Instituto da Conservacao da Natureza e da Biodiversidade, Lisboa, Portugal, pp. 184185.

Brito, J.C. \& Crespo, E.G. (2002). Distributional analysis of two vipers (Vipera latastei and $V$. seoanei) in a potential area of sympatry in the northwestern Iberian Peninsula, In G.W. Schuett, M. Höggren, M.E. Douglas \& H.W. Greene (eds.) Biology of the Vipers, Eagle Mountain Publishing, Eagle Mountain, Utah, USA, pp. 129-138.

Brito, J.C.; Fahd, S.; Geniez, P.; MartínezFreiría, F.; Pleguezuelos, J.M. \& Trape, J.-F. (2011). Biogeography and conservation of viperids from North-West Africa: An application of ecological niche-based models and 
GIS. Journal of Arid Environments 75: 10291037.

Brook, B.W.; Sodhi, N.S. \& Bradshaw, C.J.A. (2008). Synergies among extinction drivers under global change. Trends in Ecology and Evolution 23: 453-460

Buckley, L.B.; Ehrenberger, J.C. \& Angilletta, M.J., JR. (2015). Thermoregulatory behaviour limits local adaptation of thermal niches and confers sensitivity to climate change. Functional Ecology 29: 1038-1047.

Butchart, S.H.M.; Walpole, M.; Collen, B.; van Strien, A.; Scharlemann, J.P.W.; AlMOND, R.E.A.; BAILLIE, J.E.M.; BOMHARD, B.; Brown, C.; Bruno. J.; Carpenter, K.E.; Carr, G.M.; Chanson, J.; Chenery, A.M.; Csirke, J.; Davidson, N.C.; Dentener, F.; Foster, M.; Galli, A.; Galloway, J.N.; Genovesi, P.; Gregory, R.D.; Hockings, M.; KaPos, V.; Lamarque, J.-F.; Leverington, F.; Loh, J.; McGeoch, M.A.; McRae, L.; MInasyan, A.; Hernández Morcillo, M.; OldField, T.E.E.; Pauly, D.; Quader, S.; Revenga, C.; Sauer, J.R.; Skolnik, B.; Spear, D.; Stanwell-Smith, D.; Stuart, S.N.; Symes, A.; Tierney, M.; Tyrrell, T.D.; Vié, J. -C. \& Watson, R. (2010). Global biodiversity: indicators of recent declines. Science 328: 1164-1168.

Carvalho, S.B.; Brito, J.C.; Crespo, E.J. \& Possingham, H.P. (2010). From climate change predictions to actions - conserving vulnerable animal groups in hotspots at a regional scale. Global Change Biology 16: 3257-3270.

Carter, T.R. (2007). General Guidelines on the Use of Scenario Data for Climate Impact and Adaptation Assessment, Version 2. Task Group on Data and Scenario Support for Impact and Climate Assessment, Intergovernmental Panel on Climate Change, Geneva, Switzerland. Available at http://www.ipccdata.org/guidelines/

TGICA_guidance_sdciaa_v2_final.pdf. Retrieved on $02 / 01 / 2012$.

Dawson, T.P.; Jackson, S.T.; House, J.I.; Pren-
TICE, I.C. \& MACE, G.M. (2011). Beyond predictions: biodiversity conservation in a changing climate. Science 332: 53-58.

Elith, J.; Kearney, M. \& Phillips, S. (2010). The art of modelling range-shifting species. Methods in Ecology and Evolution 1: 330-342.

ESRI (2006). ArcMap 9.2. Environmental Systems Research Institute, Inc., Redlands, California, USA.

Fordham, D.A.; Wigley, T.M.L. \& BRoOK, B.W. (2011). Multi-model climate projections for biodiversity risk assessments. Ecological Applications 21: 3317-3331.

FordhaM, D.A.; Wigley, T.M.L.; WatTs, M.J. \& Ввоок, B.W. (2012). Strengthening forecasts of climate change impacts with multi-model ensemble averaged projections using MAGICC/SCENGEN 5.3. Ecography 35: 48.

Fordham, D.A.; АкÇaKaya, H.R.; Araújo, M.B.; КeIth, D.A. \& BRoOK, B.W. (2013). Tools for integrating range change, extinction risk and climate change information into conservation management. Ecography 36: 956-964.

Garrigues, T.; Dauga, C.; Ferquel, E.; ChouMET, V. \& Failloux, A.-B. (2005). Molecular phylogeny of Vipera Laurenti, 1768 and the related genera Macrovipera (Reuss, 1927) and Daboia (Gray, 1842), with comments about neurotoxic Vipera aspis aspis populations. Molecular Phylogenetics and Evolution 35: 35-47.

Gibbons, J.W.; Scott, D.E.; Ryan, T.J.; Buhlmann, K.A.; Tuberville, T.D.; Metts, B.S.; Greene, J.L.; Mills, T.; Leiden, Y.; PopPY, S. \& Winne, C.T. (2000). The global decline of reptiles, déjà vu amphibians. Bio Science 50: 653-666.

Hijmans, R.J.; Cameron, S.E.; Parra, J.L.; Jones, P.G. \& JARvis, A. (2005). Very high resolution interpolated climate surfaces for global land areas. International Journal of Climatology 25: 1965-1978.

Hoffmann, A.A. \& Sgrò, C.M. (2011). Climate change and evolutionary adaptation. $\mathrm{Na}$ ture 470: 479-485. 
IPCC (2013). Annex I: Atlas of global and regional climate projections (G.J. van Oldenborgh, M. Collins, J. Arblaster, J.-H. Christensen, J. Marotzke, S.B. Power, M. Rummukainen \& T. Zhou, eds.), In T.F. Stocker, D. Qin, G.-K. Plattner, M. Tognor, S.K. Allen, J. Boschung, A. Nauels, Y. Xia, V. Bex \& P.M. Midgley (eds.) Climate Change 2013: The Physical Science Basis. Contribution of Working Group I to the Fifth Assessment Report of the Intergovernmental Panel on Climate Change. Cambridge University Press, Cambridge, United Kingdom and New York, USA. Available at: http://www.ipcc.ch/pdf/ assessment-report/ar5/wg1/WG1AR5_Anne xI_FINAL.pdf. Retrieved on 11/01/2014.

Kissling, W.D.; Dormann, C.F.; Groeneveld, J.; Hickler, T.; Kühn, I.; McInerny, G.J.; Montoya, J.M.; Römermann, C.; Schiffers, K.; Schurr, F.M.; Singer, A.; Svenning, J.-C.; Zimmermann, N.E. \& O'Hara, R.B. (2012). Towards novel approaches to modelling biotic interactions in multispecies assemblages at large spatial extents. Journal of Biogeography 39: 2163-2178.

Knutti, R. \& SedláčEK, J. (2013). Robustness and uncertainties in the new CMIP5 climate model projections. Nature Climate Change 3: 369-373.

Lemes, P. \& Loyola, R.D. (2013). Accommodating species climate-forced dispersal and uncertainties in spatial conservation planning. PLoS One 8: e54323.

Liu, C.; Berry, P.M.; Dawson, T.P. \& Pearson, R.G. (2005). Selecting thresholds of occurrence in the prediction of species distributions. Ecography 28: 385-393.

Maclean, I.M.D. \& Wilson, R.J. (2011). Recent ecological responses to climate change support predictions of high extinction risk. Proceedings of the National Academy of Sciences 108: 12337-12342.

Madsen, T.; Stille, B. \& Shine, R. (1996). Inbreeding depression in an isolated population of adders Vipera berus. Biological Conservation 75 : 113-118.
Malcolm, J.R.; Liu, C.; Neilson, R.P.; Hansen, L. \& Hannah, L. (2006). Global warming and extinctions of endemic species from biodiversity hotspots. Conservation Biology 20: 538-548.

Mantyka-Pringle, C.S.; Martin, T.G. \& Rhodes, J.R. (2012). Interactions between climate and habitat loss effects on biodiversity: a systematic review and meta-analysis. Global Change Biology 18: 1239-1252.

Marmion, M.; Parviainen, M.; Luoto, M.; Heikkinen, R.K. \& Thuiller, W. (2009) Evaluation of consensus methods in predictive species distribution modelling. Diversity and Distributions 15: 59-69.

Martínez-Freiría, F. \& Brito, J.C. (2013). Integrating classical and spatial multivariate analyses for assessing morphological variability in the endemic Iberian viper Vipera seoanei. Journal of Zoological Systematics and Evolutionary Research 51: 122-131.

Martínez-Freiría, F. \& Brito, J.C. (2014) Vipera seoanei (Lataste, 1879) In A. Salvador (ed.) Reptiles. 2 ${ }^{a}$ Edición, Aumentada y Revisada. Series: Fauna Ibérica, vol. 10 (M.A. Ramos, coord.). Museo Nacional de Ciencias CSIC, Madrid, Spain, pp. 942-957.

Martínez-Freiría, F.; Sillero, N.; Lizana, M. \& BRITO, J.C. (2008). GIS-based niche models identify environmental correlates sustaining a contact zone between three species of European vipers. Diversity and Distributions 14: 452-461.

Martínez-Freiría, F.; Lizana, M.; Amaral, J.P. \& BRito, J.C. (2010). Spatial and temporal segregation allows coexistence in a hybrid zone among two Mediterranean vipers (Vipera aspis and V. latastei). AmphibiaReptilia 31: 195-212.

Martínez-Freiría, F.; Argaz, H.; Fahd, S. \& BRITo, J.C. (2013). Climate change is predicted to negatively influence Moroccan endemic reptile richness. Implications for conservation in protected areas. Naturwissenschaften 100: 877-889.

Martínez-Freiría, F.; Velo-Antón, G. \& Brito, 
J.C. (2015). Trapped by climate: interglacial refuge and recent population expansion in the endemic Iberian adder Vipera seoanei. Diversity and Distributions 21: 331-344.

Parmesan, C. (2006). Ecological and evolutionary responses to recent climate change. $A n$ nual Review of Ecology, Evolution and Systematics 37: 637-669.

Paulo, O.S.; Dias, C.; Bruford, M.W.; Jordan, W.C. \& Nichols, R.A. (2001). The persistence of Pliocene populations through the Pleistocene climatic cycles: evidence from the phylogeography of an Iberian lizard. Proceedings of the Royal Society of London B: Biological Sciences 268: 1625-1630.

Pauls, S.U.; NowaK, C.; BÁlint, M. \& PfenNINGER, M. (2013). The impact of global climate change on genetic diversity within populations and species. Molecular Ecology 22: 925-946.

Рімм, S.L. (2008). Biodiversity: climate change or habitat loss - which will kill more species? Current Biology 18: R117-R119.

Pleguezuelos, J.M.; SÁ-Sousa, P.; PérezMellado, V.; Marquez, R.; Cheylan, M.; Geniez, P. \& Martínez-Solano, I. (2009). Vipera seoanei. The IUCN Red List of Threatened Species. Version 2014.3. International Union for Nature Conservation, Gland, Switzerland. Available at http:// www.iucnredlist.org. Retrieved on 20 July 2013.

Pough, F.H. (1980). The advantages of ectothermy for tetrapods. The American Naturalist 115: 92-112.

Saint-Girons, H. (1981). Cycle annuel et survie de quelques vipères'Europe. Influence des temperatures exceptionnellement élevées de l'année 1976. Vie et Milieu 31: 59-64.

Scali, S.; Mangiacotti, M.; Sacchi, R. \& GenTILlI, A. (2011). A tribute to Hubert Saint Girons: niche separation between Vipera aspis and $V$. berus on the basis of distribution models. Amphibia-Reptilia 32: 223-233.

Sillero, N.; Brito, J.C.; SKidmore, A.K. \& Toxopeus, A.G. (2009). Biogeographical patterns derived from remote sensing variables: the amphibians and reptiles of the Iberian Peninsula. Amphibia-Reptilia 30: 185 $-206$.

Sillero, N.; Barbosa, A.M.; Martínez-Freiría, F. \& ReAL, R. (2010). Los modelos de nicho ecológico en la herpetología ibérica: pasado, presente y futuro. Boletín de la Asociación Herpetológica Española 21: 2-24.

Sillero, N.; Campos, J.; Bonardi, A.; Corti, C.; Creemers, R.; Crochet, P.A.; Crnobrnja Isailović, J.; Denoël, M.; Ficetola, G.F.; Gonçalves, J.; Kuzmin, S.; Lymberakis, P.; DE Pous, P.; Rodríguez, A.; Sindaco, R.; Speybroeck, J.; Toxopeus, B.; Vieites, D.R. \& Vences, M. (2014). Updated distribution and biogeography of amphibians and reptiles of Europe. Amphibia-Reptilia 35: 1-31.

Sinervo, B.; Méndez-de-la-Cruz, F.; Miles, D.B.; Heulin, B.; Bastiaans, E.; VillagránSanta Cruz, M.; Lara-Resendiz, R.; Martínez-MÉndez, N.; Calderón-Espinosa, M.L.; Meza-Lázaro, R.N.; Gadsden, H.; Avila, L.J.; Morando, M.; De la Riva, I.J.; Sepulveda, P.V.; Rocha, C.F.D.; Ibargüengoytía, N.; Aguilar Puntriano, C.; Massot, M.; Lepetz, V.; OKsanen, T.A.; Chapple, D.G.; Bauer, A.M.; Branch, W.R.; Clobert, J. \& Sites, J.W., JR. (2010). Erosion of lizard diversity by climate change and altered thermal niches. Science 328: 894-899.

Tarroso, P.; Pereira, R.J.; Martínez-Freiría, F.; Godinho, R. \& BRITo, J.C. (2014). Hybridization at an ecotone: ecological and genetic barriers between three Iberian vipers. Molecular Ecology 23: 1108-1123.

Thomas, C.D.; Cameron, A.; Green, R.E.; Bakkenes, M.; Beaumont, L.J.; Collingham, Y.C.; Erasmus, B.F.N.; Ferreira de SiqueIRA, M.; Grainger, A.; Hannah, L.; Hughes, L.; Huntley, B.; van JaArsveld, A.S.; Midgley, G.F.; Miles, L.; Ortega-Huerta, M.A.; Peterson, A.T.; Phillips, O.L. \& WilLIAMS, S.E. (2004). Extinction risk from climate change. Nature 427: 145-148.

Thuiller, W.; Georges, D. \& Engler, R. (2012) 
Package "biomod 2" Version 2.1.15. The R Foundation, Vienna, Austria. Available at http://cran.r-project/org/web/packages/ biomod2/biomod2.pdf. Retrieved on 11 June 2013.

UICN France; MNHN \& SHF (2009). La Liste Rouge des Espèces Menacées en France. Chapitre Reptiles et Amphibiens de France Métropolitaine. Comité français de l'Union Internationale pour la Conservation de la Nature, Muséum National d'Histoire Naturelle, Société Herpétologique de France, Paris, France. Available at http://www.uicn.fr/ IMG/pdf/

Liste_rouge_France_Reptiles_et_Amphibie ns_de_metropole.pdf. Retrieved on July 2013.

Ursenbacher, S.; Carlsson, M.; Helfer, V.; Tegelström, H. \& Fumagalli, L. (2006). Phylogeography and Pleistocene refugia of the adder (Vipera berus) as inferred from mitochondrial DNA sequence data. Molecular Ecology 15: 3425-3437.

VanDerWal, J.; Shoo, L.P.; Graham, C. \& Wil-
LIAMs, S.E. (2009). Selecting pseudo-absence data for presence-only distribution modeling: How far should you stray from what you know? Ecological Modelling 220: 589594.

Velo-Antón, G.; Parra, J.L.; Parra-Olea, G. \& Zamudio, K.R. (2013). Tracking climate change in a dispersal-limited species: reduced spatial and genetic connectivity in a montane salamander. Molecular Ecology 22: 3261-3278.

Wiens, J.A.; Stralberg, D.; Jongsomjit, D.; Howell, C.A. \& SNYder, M.A. (2009). Niches, models, and climate change: assessing the assumptions and uncertainties. Proceedings of the National Academy of Sciences 106: S19729-S19736.

Yousefi, M.; Ahmadi, M.; Nourani, E.; Behrooz, R.; Rajabizadeh, M.; Geniez, P. \& KaвоLI, M. (2015). Upward altitudinal shifts in habitat suitability of mountain vipers since the last glacial maximum. PloS One 10: $\mathrm{e} 0138087$. 